\title{
THE SOCIAL SECURITY ACT AND RELIEF
}

\author{
GRACE ABBotT*
}

$S^{1}$ TUDENTS of social insurance from all parts of the country, representatives of labor and employers, social workers, and insurance actuaries were called into consultation by the President's Committee on Economic Security during the summer and autumn of 1934 in connection with the drafting of his plan for a permanent program which would insure greater security for the workers. 'There was much discussion and as always disagreement among experts on many points, but the full significance of the provisions or omissions of the Act was probably little appreciated by the general public. It is therefore necessary to review briefly the steps that prepared the way for this legislation.

In contrast with Great Britain, the United States was quite unprepared for the epidemic of unemployment which spread over the land following the debacle of I929. The only public relief available was "poor relief" paid for out of locally raised taxes in thousands of "poor districts" under state laws which, like the old Elizabethan poor law, accepted responsibility for the relief of destitution but labeled the recipients paupers and imposed certain civil disabilities on those who were compelled to ask assistance. ${ }^{2}$ In some of the metropolitan cities private agencies had undertaken to carry the whole relief load and public relief had been abandoned. In mining and single-industry towns, where unemployment was almost universal and relief entirely local, the suffering was serious and general during the period from I930 to I932.

It will be recalled that the Republican administration at first stubbornly resisted the growing demand for federal relief aid. President Hoover accepted as sound the old system which left to the smallest unit of government the responsibility for dealing with the effects on the workers of an industrial crisis which he declared to be international in origin. Finally, however, the administration found itself unable to ignore the fact that

* Professor of Public Welfare Administration, University of Chicago; Member, Advisory Council to Committee on Economic Security.

I Witte, An Historical Account of Unemployment Insurance in the Social Security Act, 3 Law and Cont. Probs. I60, I6r, I63 (r936); Testimony of E. E. Witte, Hearings before Senate Finance Comm. on S. Ir 30 , Economic Security Act (74th Congress, ist session, Jan. 22, 1935), pp. 224-37, 324-36.

${ }^{2}$ Heisterman and Keener, Further Poor Law Notes, 8 Social Service Review 43-49 (I934). 
local units of government were unable to relieve hunger and that there was great restlessness in many centers. In I932 he reluctantly asked Congress to provide for loans to the states for the relief of the unemployed by the Reconstruction Finance Corporation. ${ }^{3}$ A policy of direct grants-in-aid was adopted by the Roosevelt administration in June of I933, and wide discretion given the Federal Emergency Relief Administration in determining the amounts and conditions of the grants made to the states. ${ }^{4}$ As the state emergency relief organization expanded with federal aid to meet local needs, a national public assistance system was developed. In addition to the unemployed, large numbers of needy and infirm old people, children legally entitled to mothers' aid but for whom local funds were not available, the blind, and those incapacitated from other causes were in many places added to the relief rolls. As the numbers on relief increased, it became clear that the load needed to be analyzed and special measures planned to meet the needs of special groups. By the end of I934, the President had decided to recommend to Congress a program which provided temporary work relief (WPA) for large numbers (but by no means all) of the able-bodied on relief rolls, made permanent provision for certain groups under his security program, and left to uncertain support by state and local groups the remaining employables and unemployables.

The items in the Social Security program incorporated in the administration's omnibus security bill ${ }^{5}$ were (I) a grants-in-aid system for certain groups of unemployables and for the promotion of public health, (2) a federal, compulsory, contributory old age annuity scheme for employed workers, and (3) a basis on which a federal-state unemployment system could be developed if the states passed the necessary legislation. The grants-in-aid to the states for pensions for the needy aged and blind, for aid to children dependent because of the death or incapacity of the family wage-earner, for medical care of crippled children, and for the promotion of state and local child welfare services, maternal and child health and general public health services established the policy of federal participation in the costs of these important services. While there is a difference in the terms on which these grants-in-aid are made available to the states, and the larger federal contribution for the needy aged as compared with the aid for dependent children can probably be explained only by current

\footnotetext{
3 Emergency Relief and Construction Act of 1932,47 Stat. 709 (1932); I5 U.S.C.A. $\$ 605 a$ (I935).

4 Federal Emergency Relief Act of 1933, 48 Stat. 55 (1933); 15 U.S.C.A. $\$ \S 721-22$ (r935).

5 The Wagner-Lewis Bill, 49 Stat. 620 (I935); 42 U.S.C.A. § 301 (I935).
} 
political interest in the aged, they all follow well-established traditions in federal-state relationships and, except for the old age pensions, meet needs for which services have been developing in the states for more than twenty years. ${ }^{6}$ While there are important administrative problems presented by these sections of the act the conditions set down by the federal law are few and reasonable. All the states are co-operating in the health program, and acceptance of the old age assistance and aid to dependent children would have been more prompt and widespread if it had not been for vested interest in some particular type of administration ${ }^{7}$ or partisan political opposition to the whole Security Act. The two really new undertakings are the federal old age retirement system, supported by a three per cent excise tax on payrolls and a three per cent income tax on employees, and the provisions for the federal-state unemployment system.

\section{HISTORY OF SOCIAL INSURANCE IN THE UNITED STATES}

Although the ground work for this program had been laid during the last quarter of a century, the Social Security Act has doubtless seemed to many a New Deal invention, as its passage was a New Deal achievement. Through the years, however, there has been discussion in academic and labor circles of the German social insurance system developed under Bismarck's leadership as well as of later experiments in other countries. ${ }^{8}$ When Great Britain substituted workmen's compensation for employers' liability in $1897,{ }^{9}$ enacted its old age pension law in $1908,{ }^{10}$ and in I9I 2 set

\footnotetext{
${ }^{6}$ The first state old age pension legislation was passed in 1923 , the first mothers' aid laws were enacted in rgrr, the first child health division in a State Department of Public Health (New York and Louisiana) in I9ro, and the first State Health Department (Massachusetts) in 1869 .

${ }^{7}$ In the Middle West, following the example set by Ilinois in I9rr, administration of mothers' aid laws has generally been lodged with the juvenile courts. The federal act requires as a condition for receiving federal funds administration by a single state agency having supervisory authority over the local administrative agency and giving to applicants the right of appeal from decisions of the local to the state agency. This means that under our theory of separation of powers the administration of mothers' pensions must be taken from the court and given to the local public welfare agency as the administration of old age pensions has been in Illinois. As it is an administrative rather than judicial function, this should commend itself to the courts; but many of the judges have been loath to give up the work, even though in recent years funds have been available for only a fraction of those eligible for mothers' aid while the others have been supported on general relief funds.

${ }^{8}$ Brooks, Compulsory Insurance in Germany, Fourth Special Report, U.S. Comm. of Labor (1893); Parker, British Workmen's Compensation Acts, I4 U.S. Bureau of Labor Bulletin 579 (1907).

9 "An Act to amend the $\mathrm{Law}_{\mathrm{w}}$ with respect to Compensation to Worlumen for accidental Injuries suffered in the course of their Employment," 60 and 6I Vict., c. 37 (1897).

xo "An Act to provide for Old Age Pensions," 8. Edw. VII, c. 40 (rgo8).
} 
up its compulsory contributory unemployment and health insurance system $^{\text {xx }}$ along German lines, interest in these substitutes for the uncertainties and humiliations that characterized poor relief increased in the United States.

The first security legislation was enacted in this country a quarter of a century ago when the first mothers' aid and workmen's compensation laws were passed. Prior to IgII we had, in effect, said to the widow of a working man who left her without means for the support of her children through the school period that she had two courses open to her: she could surrender her children to a public or private orphanage (in some places it was the poor farm) or attempt to run a boarding-house or do some work outside the home to support herself and her children. The bereaved mother was not told that the records showed that her health would probably break under the double strain of homemaker and wageearner; that she would be able to give only very inadequate supervision to her children and if they became demoralized and delinquent in consequence, as the records showed frequently happened, society would then take the children by legal process and begin the costly process of their re-education in an institution for delinquent children. Mothers' aid offered her a third choice, public aid for the children in their own home before they became delinquent. The first of such acts was passed in I $9 I^{12}$ at the request of Merritt W. Pinckney, judge of the Juvenile Court of Cook County, who told the legislature that he was unwilling to continue to order children removed from their mother's care and placed in an institution on the ground of poverty alone. What the new system was to be was not too clear either to Judge Pinckney or to those who supported or opposed the legislation. No other state or nation had attempted to meet this problem as he proposed. Still with no preliminary discussion of the law, no canvassing of the probable number of children eligible for care under the law or what the costs would be, the Hlinois legislature agreed that some better system could be worked out and gave the juvenile court judges of Tllinois authority to make the experiment. Tested by experience and amended to provide administrative safeguards, it became clear to the public that "mothers' aid" or "mothers' pension" laws, as they were first called, recognized that long-time care would be necessary for these chil-

II "An Act to provide for Insurance against Loss of Health and for the Prevention and Cure of Sickness and for Insurance against Unemployment and for purposes incidental thereto," I and 2 Geo. V, c. 55 (Igrr). Although passed in Igrx, the Act did not go into effect until the following year.

I2 Ill. L. IgII, p. I26. 
dren; that it was socially desirable that mothers should remain in their own homes and care for their own children; that it was cheaper for society to pay for their care in this way than in institutions or in foster homes. For these reasons, it was in the public interest that assistance adequate for maintaining the children in a reasonable standard of health and comfort should be assured the mother. This new method of care was promptly accepted and enacted into law by state after state. ${ }^{\mathrm{I3}}$ Although often poorly drawn and inadequately financed by local governments, and too often limited to destitute mothers only, mothers' aid laws in a large number of counties lifted many dependent children out of the pauper class and provided for their needs on a new, more generous, and more secure basis than had the old poor law or private charity. But the laws were usually permissive and not mandatory, funds were supplied by local taxes, and many counties made inadequate or no provision for carrying out the state laws. The Social Security Act, providing that federal grants-in-aid for dependent children will be paid the states on condition that the state participates in the costs, will remedy the disadvantage of complete reliance on local funds and promote better administrative procedure. If accepted in Illinois, federal aid would be available for some I4,000 such children who have been on relief.

It was also in I9II that the New York legislature undertook to bring security to another and larger group-the victims of industrial accidents. Under the limitations and legal uncertainties of employers' liability as developed under the common law, the injured workers were frequently compelled to turn for assistance to public poor relief or to private charity. To be sure, when it was clear that the employer had been guilty of negligence and that neither the worker nor his fellow-servants were negligent, large sums could be collected but usually only after long-drawn-out and costly legal battles. In most cases all the costs of the accident fell on the injured workman and his family or, when he was destitute, on the taxpayers rather than on industry. ${ }^{14}$ In the first part of this century evidence of the social costs of this system of compensating the injured workman

${ }^{3}$ By I913, I9 states; by I92I, 40; and by 1934 all the states except Georgia and South Carolina had enacted some kind of mothers' aid law, as had the District of Columbia, Alaska, Hawaii, and Porto Rico. See Mothers' Aid, U.S. Children's Bureau pub. no. 220 (I93I).

${ }^{14}$ See Hearing Held before the Employers' and Workmen's Compensation Commission, 2 U.S. Senate Doc. no. 338, 62d Congress (2d session I912); Report of the Employers' Liability Commission of the State of Illinois (I9ro); Downey, Workmen's Compensation, c. I (I924); Eastman, Work Accidents and the Law, pt. II, II9-52 (I9I6); Heinrich, Cost of Industrial Accidents to the State, the Employer, and the Man, U.S. Bureau of Labor Statistics, bull. no. 536, p. I7I (I93I); Campbell, Industrial Accidents and Their Compensation (I9II). 
was canvassed by official commissions, social agencies, and individuals. ${ }^{15}$ The conclusion reached was that the prompt payment of definite amounts fixed by statute was the way to give the workers greater security against this hazard. At first held unconstitutional by the New York courts, an amended New York law and laws enacted by other states were eventually sustained. The workmen's compensation laws, adopted in thirty-one states by I9I6 and in all but Mississippi and Arkansas to date, have been frequently amended as experience has indicated. At every regular session of the New York legislature, for example, from IgI2 to the present some changes have been made in the workmen's compensation law. Just as mothers' aid legislation supplied an American precedent for old age assistance, so we have drawn heavily on our experience with workmen's compensation in setting up an unemployment compensation system in the United States.

Evidence of public interest in other forms of social insurance appeared at the same time that the first workmen's compensation and mothers' aid laws were being passed. The Progressive Party platform of 1912 , written by social reformers and accepted by Theodore Roosevelt as a way of differentiating his program from that of Woodrow Wilson, contained endorsements of the general principle of social insurance and specifically mentioned workmen's compensation, old age pensions, and health insurance. ${ }^{16}$ Between I9I7 and I920 several state legislatures set up official commissions to investigate and report upon "health insurance"17 and old age pensions, ${ }^{18}$ largely as a result of the efforts of the American Association for Labor Legislation, of which Professor Commons may be said to have been the founder. But the war and the noisy materialistic period which followed it put a temporary end to the social reform movement which had gained considerable momentum during the first sixteen years of this century.

15 Report of the Boston Committee on Relations between Employer and Employee (1904); Report of the Industrial Insurance Commission to the Governor of Illinois (I907); Report of the Employers' Liability Commission of the State of Illinois (rgro); Campbell, op. cit. supra note 14 ; Eastman, op. cit. supra note I4; see, generally, American Labor Legislation Review.

${ }^{16}$ Platiorm of the Progressive Party adopted at its First National Convention, Chicago, August 7, 1912, section on Social and Industrial Justice.

17 California, rgr7; Massachusetts, I9r7 and I9r8; New Jersey, Igr8; Connecticut, Igrg; Illinois, rgr9; New York, I9I9; Ohio, I919; Pennsylvania, r919; Wisconsin, 19r9.

${ }^{8}$ The most important early reports on this subject were made by the Massachusetts Commission on Old Age Pensions, Annuities and Insurance, I9ro; the Wisconsin Industrial Commission, I9r3; the California Social Insurance Commission, x9r7; the Ohio Fiealth and Old Age Insurance Commission, rgr9; the Pennsylvania Commission on Old Age Pensions, Igrg. 
OLD AGE PENSIONS

Interest in old age pensions was the first to develop in the post-war period. Montana adopted an old age pension law in $1923 ;^{: 19}$ next the Fraternal Order of the Eagles advocated state laws providing pensions for the needy aged and was soon supported by other fraternal orders; organized labor supported this type of pension, ${ }^{20}$ and a new organization, the American Association for Old Age Security, became active in $x 927$, while the American Association for Labor Legislation was renewing its efforts. By 1932 , seventeen states and Alaska had adopted old age pension laws. Finally, as the Townsend movement got under way, politicians realized that a ground swell of popular demand for generous care for the aged was spreading to the East from California, and it became apparent that Congress might be induced to provide federal grants-in-aid for state old age pensions, and a number of bills were introduced in Congress between I927 and I934..$^{2 x}$ Until the Townsend Old Age Revolving Fund was announced, most of these proposals contemplated pensions for the needy aged only. Like the mothers' pension laws and the British Old Age Pension Act of 1908, they were to substitute for the harsh uncertainties of poor relief a regular grant which would lift the dependent old people out of the pauper class and enable them to live in relative security a little above the poor relief level. ${ }^{22}$

The financial unsoundness of many of the retirement schemes inaugurated by industrial establishments became apparent during the depression. Labor had never liked the employer control of these systems, and in $1929^{23}$ the American Federation of Labor adopted a resolution favoring a national compulsory system. The first compulsory contributory retirement bill to be passed by Congress was the Railroad Brother-

19 A loosely drawn law was passed in Arizona in 1914 and was declared unconstitutional shortly thereafter, Board of Control v. Buckstegge, I8 Ariz. 277, I58 Pac. 837 (r916).

${ }^{20}$ That is, non-contributory pensions. It is only since the depression that labor has favored a government retirement scheme.

${ }^{2 x}$ Congressman Victor Berger introduced a widely discussed bill providing for federal pensions in rgrr. Congressman William B. Wilson, later Secretary of Labor, had introduced one a few years earlier with labor support. None, however, received a favorable committee report until r932.

22 In addition to the Old Age Pension law of 1908 , the British had added compulsory contributory old age, orphans' and widows' benefits to its health insurance system. See 55 and 16 Geo. V, c. 70 (r925). The insurance system was also spreading rapidly in Europe. See International Labour Office, Studies and Reports series M (x925).

${ }^{23}$ Report of the Proceedings of the Forty-ninth Annual Convention of the American Federation of Labor 50 (r929). 
hood bill in $1934,{ }^{24}$ shortly after President Roosevelt appointed the Cabinet Committee on Economic Security to canvass the whole subject. With some amendments, Titles II and VIII of the Social Security Act provide for federal old age annuities as recommended by the Committee ${ }^{25}$ and by the President in his message to Congress in January, I935. ${ }^{26}$ Under this Act, old age assistance is provided for the needy aged at a maximum, so far as federal reimbursement is concerned, of $\$ 30$ a month, and the federal old age benefits for the employed workers included in the compulsory contributory system will, some forty years hence, provide annuities amounting to a maximum of $\$ 85$ a month, the exact amount being determined by the earnings of the employee with, however, a favorable weighting for the lower paid group. This program should eventually take from relief rolls and poor farms all except a very few old people who have not been employed or cannot meet the residence or other requirements of the state old age assistance laws.

Because unemployment compensation presents problems which are less well understood than those involved in an old age retirement system or the grants-in-aid program of the Social Security Act, such space as remains will be given to the scheme for protection against unemployment proposed by the Security Act. It should, however, be noted that the old age assistance and annuity provisions are certain to come in for criticism and amendment. The three per cent tax on their wages which employees must pay for their annuities, the fact that in addition to excluding farmers, domestic servants, and some other employed persons, the Act makes no provision other than old age assistance for married women not gainfully employed, and that the younger workers will for a generation at least pay a large part of the pensions of the older group, or, to put it in another way, the fact that a considerable portion of the costs are not, as in England, to come from the general treasury, are the criticisms of the scheme which should be considered.

\section{UNEMPIOYMENT COMPENSATION}

This form of social insurance in which Great Britain pioneered in I9II has been copied by most European states since the War. American interest in the scheme grew after the depression when unemployment reached a depth and breadth never before experienced, although every effort was made by opponents to the scheme to discredit it by stories of the so-called "anomalies."

${ }_{24}$ "An Act to provide a retirement system for railroad employees, to provide unemployment relief; and for other purposes," 48 Stat. I283 (I934).

${ }^{25} 79$ Congressional Record $547-48$ (1935). $\quad{ }^{26} I d$. at 546. 
The questions to be considered in a decision as to the unemployment compensation system which the President proposed are ( $\mathrm{I}$ ) the need for some system of unemployment benefits, (2) the appropriateness of the system for which it provides a basis, and (3) its constitutionality. The question of constitutionality will not be discussed here. Much has already been written on the subject, and there will be more predictions until the United States Supreme Court finally speaks. The constitutionality of the excise taxes levied by the Security Act for old age benefits, and unemployment compensation with the credit of 90 per cent if the state passes an unemployment compensation law meeting the conditions of the Security Act, and of the state employment laws, ${ }^{27}$ will probably be before the United States Supreme Court in I937. In the event that the decision goes against the federal or the state laws, we shall have to return to the question of the need for some such system. Every important industrial country in Europe has decided that it can no longer rely on poor relief for the unemployed as the United States has done in the past. Whether the United States can find another way without amendment of the Constitution may be the question before us in 1937 .

THE NEED FOR UNEMPLOYMENT COMPENSATION

The need for public provision of some kind of unemployment compensation scheme grows out of the fact that unemployment is one of the hazards of industry which has tragic consequences for the worker and his family. It is one for which he is not responsible and against which large numbers of workmen cannot hope to protect themselves.

At the peak of the present depression there were some 20,000,000 persons on relief, approximately $7,000,000$ of whom were children under sixteen years of age. These children-the older ones at once and the younger ones gradually-learned that the independence of their family group was gone, that defeat and despair now lived with them. What this experience has done to these millions of children we do not know. Certainly not the same thing to all of them, but that the effects of this experience will be with them to the end of their days can hardly be questioned.

But unemployment is not exclusively a depression problem. At all times, under our industrial system, there is unemployment. Industry counts on a reserve labor supply to meet its peak demands and has in the past dismissed its workers without notice when demand fell off, with no

${ }^{27}$ The New York Law was upheld by the New York Court of Appeals in Chamberlain v. Andrews, 2 N.E. (2d) 22 (N.Y. I936). The Washington law was held invalid by the state supreme court, however, in Johnson v. State, 60 P. (2d) 68r (Wash. 1936). 
responsibility to them or to the community for their maintenance until they were again needed. Other causes leave large numbers of workers out of work. The seat of an industry may change from one part of the country to another; demand may drop permanently. Changes in industrial organization are constantly giving and taking away employment. The growth, the life of an industry, requires replacement of old machines, old processes. Slowly, acquired skills become no longer necessary. New skills are usually developed more successfully by younger workers, and the older but by no means superannuated workers frequently find themselves destitute or pushed down into the less skilled or unskilled group. Too often emergence from a lower level is impossible. Like the actor who cannot afford to take minor parts after he had played leading rôles, so the skilled worker knows that employment at unskilled work will affect adversely his further earning capacity.

Change and growth have especially characterized American industry. While these changes have eventually meant industrial progress, more comforts and a better standard of living for us all, as John Stuart Mill warned Great Britain nearly a century ago, one group of workers is "sacrificed to the gains of their fellow citizens and posterity." 28

An investigation made by the Children's Bureau ${ }^{29}$ showed how in I92I the workers who managed to keep off relief lost their homes because payments could no longer be made, sacrificed their insurance, and accumulated debts. Their children frequently left school, and their wives their homes for work which was available for them at low wages. A study of railroad workers made in 1933 showed similar losses and also how promptly essentials like milk for the children were eliminated from food budgets when there was unemployment or reduction of wages through demotions. ${ }^{30}$

But there are, too, losses to the worker through unemployment when industry is expanding and jobs are plentiful. Every social worker has had to grapple with the technological unemployment which characterizes prosperous times. As we have had an inadequate employment service, no retraining programs and no unemployment benefits, the discarded worker and his family in the past have been left to make their own adjustments and to meet all the costs involved in sweeping industrial changes. When their funds were exhausted, their only resource was poor relief. The so-

${ }^{28}$ See Beveridge, Unemployment III (rev. ed. r93r).

${ }^{29}$ Lundberg, Unemployment and Child Welfare, U.S. Children's Bureau pub. no. 125 (I923).

${ }^{30}$ Goodrich, Earnings and Standard of Living of $\mathrm{r}, 000$ Railway Employees during the Depression (1934). 
called "rugged individualism" and "freedom from regimentation" of the past were bought at a very heavy cost for the worker and his children.

Even so, in normal times successful adjustments were always taking place, but there were also large numbers of individuals who for many different reasons found it impossible to adapt themselves immediately to new conditions. With stabilization accomplished, change comes again, suddenly and disastrously for many individuals. Unemployment, inability to keep a job, finally becomes chronic. Social and individual characteristics which we now recognize as symptoms of mental disease make the worker unemployable.

Payment of a percentage of his wages for a fixed period gives the worker an opportunity to adjust himself without loss of status or demoralizing anxiety. Without such assistance even in minor depressions there are serious individual and social losses. It is against this "normal" unemployment and the minor depressions that unemployment compensation is a protection.

The black years from 1930 to 1936 demonstrated on a grand scale the injustice and social losses which result from making no provision for the unemployed worker. When he became destitute, we have, to be sure, given poor relief, but usually on a scale so inadequate that it accelerated the demoralization of the worker and made the recovery of his old status more difficult. In I934 President Roosevelt decided that the attempt to find a better way must not await recovery.

With the experience of England available, it was inevitable that some adaptation of the British system to American needs would be made. Successfully started for seven industries in I9I2, the British unemployment fund had a balance when the war began, ${ }^{3 x}$ and emerged from the

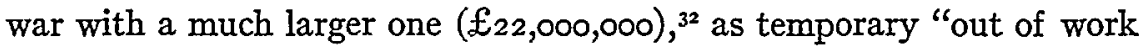
donations," larger than the unemployment benefits, were paid to soldiers and munitions workers after the armistice. But in 1920 , with a reserve fund accumulated for some $4,000,000^{33}$ workers, the law was amended by Parliament to include practically all employed persons earning less than $\$ \mathrm{I}, 250$ a year, ${ }^{34}$ or approximately II,000,000 persons. This meant that some 7,000,000 for whom reserves had not been accumulated became

${ }^{31}$ I9I3 and I9I4 were years of abnormal demand for workers. See Davison, The Unemployed 79 (1929).

32 Id. at 87 .

33 The Act of IgII covering 2,250,000 was amended in I9r6 so that the numbers paying into the reserve in I920 were approximately 4,000,000.

34 "An Act to amend the Law in respect of Insurance against Unemployment," Io and II Geo. V, c. 30 (1920). 
eligible for benefits, if unemployed. Following this politically generous step came the post-war depression from which England was emerging when the world-wide depression broke in r929. During all but two years of the period I920 to I934, the unemployment insurance fund showed a deficit while, at the same time, there was a public demand that unemployed workers be continued on "supplemental" or "extended benefits" after their benefits under the law were exhausted. The law was amended again and again during this period, and confusion and criticism of the "anomalies" which developed continued. But the British system survived, was reorganized by the National Government in I934, showed a balance last year and a larger one this year. Today, according to Sir William Beveridge, no responsible section of the British public advocates its abolition. Yet, opponents have not given up their criticism, and enthusiasts for insurance have discovered in the "hard core of chronic unemployment" conditions for which a money payment is not the complete answer.

As Americans studied the workings of the British system during the years when it was most criticized, they found it impossible to escape the conclusion that the system of prompt, regular payment of out-of-work benefits to unemployed workers had sustained buying power and so cushioned the effects of the depression for business as well as provided relief for the workers.

Iike England twenty-five years ago, the United States lacked the basic information on which the costs of any proposed system could be determined. The United States Bureau of the Census enumerated the unemployed in I93I, and another enumeration was made in I933. The Bureau of Labor Statistics had expanded its employment reports since the depression so that information on depression conditions is available. But the pre-depression data on which the government actuaries based their estimates of the extent and duration of unemployment in normal times are fragmentary and local. The British statistics covering the last sixteen years show wide variation in the incidence of unemployment between different industries, as well as in the same industries in different parts of the country and under different management, and do not supply a basis for determining the cost of unemployment benefits in the United States.

Moreover, British experts are not agreed that unemployment is an insurable risk. Some regard the unemployment benefits as a form of relief placed on a definite, legal basis-a form of social insurance, but not insurance in a commercial sense. Sir William Beveridge, the father of the British system, and with him a large section of the British public, still 
clings to the insurance principle. Beveridge would keep the so-called "earned benefits" strictly within the bounds of the funds collected from employees, employers, and appropriated by the government for this purpose. But the experience during the period from 1920 to 1934 showed that this was impossible unless some provision other than poor relief were made for those for whom the fixed benefits are inadequate in amount, or for whom the period of payment is not long enough. The British way out of the dilemma, with which they struggled for more than ten years, provides a second system for the relief of those who are unemployed and in need after their so-called insurance benefits are exhausted. The proposal of the National Government adopted by Parliament in $1934^{35}$ provides, first, that unemployment benefits for those who have had the required number of weeks of employment ${ }^{36}$ become payable after a waiting period of six days. The amount of the benefit is approximately $\$ 4.00 \mathrm{a}$ week for a maximum period of twenty-six weeks. Employers, employees, and the government each pay a flat rate of twenty cents a week, ${ }^{37}$ which has more than paid the costs during the past year. For those who are still unemployed at the end of twenty-six weeks, and who are in need, Unemployment Assistance, nationally administered and paid from the exchequer, is available to all who are insured under the Health Insurance Act, which is more inclusive than the Unemployment Insurance Act.

This scheme was adopted to save the insurance basis of the unemployment benefits and also because it became evident to those administering unemployment insurance that "nothing but individual treatment (what we would call case work) with opportunities for re-training was of any use for chronic cases of unemployment." This national Unemployment Assistance scheme which is based on a "means test," i.e., evidence of need, was so unpopular at first, that its abandonment by the National Government was freely prophesied a year ago. It has, however, survived and is an integral part of the present British plan for dealing with unem-

35 "An Act to amend the Unemployment Insurance Acts, 1920 to I933, and to make further provision for the training and assistance of persons who are capable of, and available for, work, but have no work or only part-time or intermittent work; and for purposes connected with the matters aforesaid," 24 and 25 Geo. V, c. 29 (I934).

${ }^{36}$ From 1928 to 1934 the requirement was thirty weeks in two years. Under the Unemployment Act, 1934, an insured contributor who has contributed regularly for at least five years and not drawn any benefit during that time, may get an extension of benefits for another six months. See 24 and 25 Geo. V, c. 29, pp. 193-94 (1934). See also Hill and Lubin, The British Attack on Unemployment $157-67$ (1934), and Davison, The New British Unemployment Act, 8 Social Service Review 605 (1934).

37 The rates of contributions and benefits are less for women and juveniles. An additional benefit of $\$ 2.25$ for a dependent adult and 50 cents for a child is also given. 
ployment. Of the approximately fourteen per cent of the workers of Great Britain who were unemployed last summer, about half were being paid insurance benefits and half unemployment assistance. ${ }^{38}$

Although much influenced by the British scheme, Americans have greatly modified it by drawing heavily on their experience with workmen's compensation. Wisconsin adopted in $193^{39}$ an unemployment compensation law which differed from the British in many particulars. The most important differences under the Wisconsin scheme and the socalled "American Unemployment Compensation Plan," advocated by the American Association for Labor Legislation, are that each industry pays the whole cost of the unemployment benefits fixed by the law, with no contributions from employees or the state; employers' reserves are built up, not by flat contributions but by a percentage of the payroll (originally two per cent of the payroll in Wisconsin, now 3 per cent), and the benefits are not equal but like "workmen's compensation" are fifty per cent of wages for a fixed period with a minimum and maximum amount specified in the law.

The merits of the "Wisconsin plan" as compared with the plan proposed by the Ohio Unemployment Commission in 1932 but not adopted by the Legislature have been much discussed. The latter proposes pooled funds, contributions by employees as well as employers, but like the Wisconsin Act benefits based on earnings. Other states appointed commissions from I930 to I935 to investigate the subject and report a plan. ${ }^{40}$ As Governor of New York, Roosevelt assembled a regional conference to consider the subject. In 1932 the American Federation of Labor for the first time went on record in favor of unemployment compensation. ${ }^{4 I}$ Finally, the Wagner-Lewis bill, providing for a federal tax with

${ }^{38}$ Beveridge, The Work of the Unemployment Insurance Statutory Committee, $x_{7}$ (British) Social Service Review I27, I30 (I936).

39 Wis. L. 193I, c. 20.

40 California State Unemployment Commission, November, I932; Connecticut Unemployment Commission, December, I932; Maryland: Baltimore Municipal Commission on Unemployment Stabilization, 1932; Massachusetts: Special Commission on Stabilization of Employment, final report, I932; Special Commission to Investigate Unemployment Insurance, November 30, r934; New Hampshire Commission on Unemployment Reserves, r934; New Jersey Social Security Commission, 1936; New York: Governor's Commission on Unemployment Problems, I930; Joint Legislative Committee on Unemployment, I933; Ohio Commission on Unemployment Insurance, I932; Oregon: Commission to Investigate the Subjects of Old Age Pensions, Old Age Insurance, and Unemployment Insurance, I933; Unemployment Insurance Commission of the State of Oregon, 1935; Pennsylvania: Committee on Unemployment, I931; State Committee on Unemployment Reserves, I933; Virginia Commission on Unemployment Insurance, 1934.

4I Report of the Proceedings of the Fifty-second Annual Convention of the American Federation of Labor $39-44$ (1932). 
an offset if the state adopted a satisfactory unemployment compensation law similar to the plan incorporated in the Social Security Act, was introduced in I934. At hearings on this bill labor leaders, associations interested in labor legislation, economists, a few employers and other individuals supported the measure. The President approved the measure but did not put it on his "must" list in the spring of 1934 and no action was taken by either House or Senate Committee at that session. However, the creation by executive order of a Cabinet committee on Economic Security just before the adjournment of Congress, and the issuance of a statement by the President on the subject, meant that Congressmen elected as Roosevelt supporters in the autumn of 1934 were obligated to support an unemployment compensation law in the next Congress.

The first thing to be noted with reference to the unemployment scheme which the Security Act, finally adopted in August, r935, is that unlike the British act, it provides not a national, but a federal-state system. The act passed incorporates the provision of the first Wagner-Lewis bill for federal tax of three per cent on payrolls to be collected from employers ${ }^{42}$ with a credit of ninety per cent ${ }^{43}$ in a state which has adopted an unemployment law which meets the conditions laid down by the federal act. The most important of these conditions are collections of at least a three per cent payroll tax from employers, deposit of the funds in the federal treasury, and payment of all the funds collected for unemployment benefits through the federal-state employment service or some other agency approved by the Federal Security Board. Unquestionably, with many industries organized on a national basis, with the demand for labor reaching out across state lines, and with very uneven administrative standards in the various state departments of labor, a national system would have many advantages over a state system. To those who advocate the insurance principle with pooled funds, a national scheme has the additional advantage of including much larger numbers and balancing bad employment conditions with heavy drains on the funds of one state against better conditions in others. To those who favor employers' reserves, the Wisconsin ${ }^{44}$ as compared with the New York system, the payment of benefits to the workers in a depressed area or industry, after its own funds are exhausted, is not the test of the ultimate usefulness of an unemployment compensation system. They argue that as it is generally cepted.

$4^{2}$ Of eight or more persons with farm employees, domestic servants, and a few others ex-

43 The remaining ten per cent is available for federal and state administrative costs.

44 Hoar and Brandeis, Economic Bases of the Wisconsin Unemployment Reserve Act, 23 American Labor Legislation Review I23-30 (1933). 
agreed that a reserve adequate for a deep depression such as came in I929 cannot or should not be accumulated, and a considerable amount of our normal unemployment can be prevented by wise management, the payment of benefits by the individual employer is the best way to promote stabilization. An insurance system which conceals the facts as to unemployed paid from a common pool will tend, it is argued, to perpetuate existing conditions unfair to the worker, and unfair to the employer who succeeds in stabilizing his production. It will be recalled that twenty-five years ago it was similarly argued that payment for work accidents would lead employers to install safety devices and encourage safe practices by the worker, and so reduce the number of accidents. 45 While the workers would like to prevent unemployment and work accidents, they have little hope that much will be done to eliminate either. To them, assured assistance for the unemployed is the objective, and they know that pooled funds is the surest method of providing a measure of relief ${ }^{46}$ for all the unemployed. Because of the variations in the labor cost and in the degree of stabilization, Cotter and Phelps, writing in the Wall Street Journal, conclude that the "consensus in employer circles appears to favor a pooled plan with employer merit ratings." 47 Utility companies, service and consumer goods industries with relatively stabilized employment, would gain under the reserved scheme, while, for example, in coal, steel, copper, which show great fluctuations in employment, the tax rate would be much higher than under a pooled scheme.

The federal-state system provided by the Security Act was chosen for several reasons. First, because of constitutional difficulties. For, although among the constitutional lawyers consulted, there was no agreement that the federal-state system was a safer gamble than an exclusively federal system, the fact that, in the event that the federal act was declared unconstitutional, the state laws would remain ${ }^{48}$ had great weight with those

${ }_{45}$ The fact that the so-called "self-insurers" have a better record in accident prevention than those insured with private companies or state funds is pointed to as evidence of the value of fixing the costs on the individual company.

${ }^{46}$ Testimony of Wm. Green, Hearings before Senate Finance Comm. on S. Ir30, Economic Security Act (74th Congress, Ist session, Jan. 22, 1935), pp. I54-56, I64.

47 Cotter and Phelps, Your Securities under Social Security II5 (r936).

${ }^{8}$ The usefulness of this argument has been largely negatived by the provisions in all the state laws enacted to date except those of New York, Washington and the District of Columbia. Statutes in these other states contain the proviso that if Title III or Title IX of the federal Security Act are held "unconstitutional or inoperative," or "amended, repealed, affected, or otherwise changed," etc., the state law becomes inoperative. Massachusetts provided that its state law should not become inoperative with the federal law if II of the following states still imposed burdens on employers substantially the same as those imposed by the Massachusetts law: Alabama, Connecticut, Delaware, Georgia, Tllinois, Indiana, Iowa, Maine, Maryland, 
who favored the federal-state scheme. Second, there was disagreement among experts and in Congress as to employee contributions and as to the merits of the plant reserve of pooled funds or pooled funds with merit ratings. With no experience ${ }^{49}$ on which to base a judgment as to the relative merits of the several schemes, it was clear that it would be extraordinarily difficult to pass a national law which required decision on these points without years of delay and fruitless discussion. Also, experience as to the amount of benefits that a given tax rate would provide if a national scheme were adopted was entirely lacking. For these reasons, and because of the administrative difficulties of launching a national system with no prior experience, some who favor a national scheme believed that a period of experimentation with different systems would supply the evidence on which the public could form conclusions as to which system was, in fact, the one which would best meet the needs of the workers.

There were objections also to the accumulation of any kind of reserves and to the payroll tax. The Lundeen bill, which had some supporters but which was little discussed, provided that out-of-work benefits should be paid to all the unemployed during the whole period of their unemployment from the national treasury.

A payroll tax may be objected to for many reasons. Beveridge ${ }^{50}$ has pointed out that "on fiscal grounds a tax on employment is hard to defend; it does not come out of profits; it goes directly into costs of production, it discourages a desirable activity," so that "if unemployment insurance is going to become unemployment relief subject to the Labour Exchange test," financed by means of a "direct tax on employment it has little to commend it." It was for this reason that he argued that the insurance principle of limited benefits paid out of the special tax on employers and employees, with a fixed contribution by the government, should be strictly adhered to and the unemployment insurance system not made a system of relief for the unemployed.

There was much discussion in Washington at the Conference called in the autumn of 1934 and in the Advisory Council appointed by the President, as to whether a tax should also be levied on employees. Those who wanted to see the English system adopted with very few modifications and with close adherence to private insurance principles-Paul $\mathrm{H}$.

Michigan, Minnesota, New Hampshire, New Jersey, New York, North Carolina, Ohio, Pennsylvania, Rhode Island, South Carolina, Tennessee, Vermont.

49 English and Continental experience has been with a pooled system only, and all except Russia require employee contributions. Voluntary experiments in a few industries in the United States with the individual reserve system furnished no adequate basis for judgment.

so $O p$. cit. stipra note 28 , at 408 . 
Douglas, I. M. Rubinow, and Paul Kellogg, for example-favored contributions by the workers. Employers generally, although not universally, also favored employee contributions. The only argument they could offer to Labor was that if they contributed they would have more voice in the administration of the act, and the benefits would be larger or longer continued, or both. Labor's participation in the administration of workmen's compensation has resulted from its political power, as the employee makes no contribution to the costs, so that the first of these arguments has little merit. Probably the real reasons why the employers advocated employee contributions were that they (I) would make the scheme less popular with the workers and (2) would hold down future demands for larger benefits. President Green of the American Federation of Labor summarized in his statement before the Senate Finance Committee ${ }^{\text {st }}$ Labor's objections to employee contribution as follows:

There are many reasons why organized labor opposes compulsory employee contribution to unemployment funds. The primary reason is that wages are so low for the vast majority of wage-earners that they simply will not permit even very small contributions to such fund. Employee contributions would literally have to come out of the bread and butter of the wage-earner. . . . .

A second reason why we oppose compulsory employee contribution is that contributions for unemployment insurance paid by employers are ultimately passed on to the consumers, while the contributions of the workers must come out of their net earnings, and cannot be shifted in any way..$^{52}$

The costs of unemployment compensation and old age benefit will, of course, vary greatly from industry to industry, depending on the labor cost in production. An attempt to estimate the costs to the consumer or to the share-holder was made in a series of articles by Arundel Cotter and Thomas W. Phelps. 53

Information as to labor costs in relation to total production costs, profits, etc., during the past five years was supplied the authors by 300 leading corporations. Their analysis showed interesting differences in the relative costs when the old age and unemployment excise taxes on payrolls reached the maximum. For example, the tax for oil would amount to four-fifths of one per cent of total sales while for coal would be three per cent. ${ }^{54}$ If the reserve plan were adopted, coal's troubles would be increased, since it is a seasonal industry. According to the report submitted by United States Steel on a ten-year average from 1925 to 1935 , the added

${ }^{5}$ See Testimony of Wm. Green, op. cit. supra note 46 , at 164. $5^{2} \mathrm{Id}$. at 164 .

53 Cotter and Phelps, op. cit. sitpra note 47 . This work is the compilation (with slight revision) of a series of articles appearing in the Wall Street Journal in the early part of 1936.

$54 \mathrm{Id}$. at 98 . 
cost per ton of steel would have been $\$ 0.93$ for unemployment compensation and $\$_{1} .84$ for unemployment plus old age benefits. If this added cost had been taken from profits, the dividends in 1929 , the authors find, would have been reduced from $\$ 2 \mathrm{I}$.I7 per share to $\$ \mathrm{xg} .69$, and in 1932 the deficit would have been increased by about $\$ 4,000,000.55$ On the information submitted by meat packers, Cotter and Phelps estimated that "about one-tenth of a cent a pound is what it will cost to have social security with your meat when the new law is in full effect." ${ }_{56}$

\section{STATE UNEMPLOYMENT COMPENSATION LAWS}

To date, fifteen states and the District of Columbia have moved to secure for their unemployed workers the funds being collected through the payroll tax. ${ }^{57}$ On the points of controversy to which reference has been made, only New York has an exclusively pooled fund, and only Wisconsin the reserve system,,$^{58}$ although the Oregon and Indiana laws have many of the reserve features. All the other states provide for pooled funds with merit ratings for employers based on their employment record. The basis of the merit rating is not worked out in detail in most of the laws, and administrative procedures have not as yet been determined. As to employee contributions: New York, Utah, Wisconsin, Oregon, Mississippi, South Carolina, and the District of Columbia do not tax the employees, while New Hampshire, Massachusetts, Rhode Island, Indiana, California, Washington, Idaho, Alabama, and Louisiana provide for deductions from wages, usually of one per cent of wages, or one-half the employer contribution.

\section{ADMINISTRATION}

The administrative problems that are certain to arise in the administration of the Act are little appreciated. There is a vast clerical job in record

$$
55 \mathrm{Id} \text {. at } 12 . \quad 5^{6} \mathrm{Id} \text {. at } 29 .
$$

57 Alabama: Ala. L. 1935, c. 447; L. 1936, Flouse Bill no. 204 (Approved, April 21, 1936). California: Cal. L. 1935, c. 352. District of Columbia: Public No. 386, 74th Congress, as amended by Public No. 446 (Approved, Feb. 13, 1936) and Public No. 762 (Approved, June 23, 1936). Idaho: Idaho L. I935, c. I2. Indiana: Ind. Acts x936, c. 4 (special session). Louisiana: La. L. 1936, H.B. no. 82. Massachusetts: Mass. L. 1936, c. 479; L. 1936, cc. I2, 249. Mississippi: Miss. L. 1936, c. 176; L. 1936, H.B. no. ro (special session). New Hampshire: N.H.L. 1936, cc. 99, 142; L. 1936, c. 3. New York: N.Y.L. 1935, c. 468; L. 1936, cc. II7, 697. Oregon: Ore. L. I935, c. 70 (special session). Rhode Island: R.I.L. 1936, c. 2333. South Carolina: S.C. L. I936, Act. 768. Utah: Utah L. 1935, c. 38, as repealed by L. 1936, House Bill no. 2 (Approved, Aug. 27, 1936 in special session). Washington: Wash. L. 1935, c. I45. Wisconsin: Wis. L. I93I, c. 20 as amended (special session); L. I933, cc. I86, 383 ; L. 1935, cc. 192, 272, 446 .

${ }^{8} \mathrm{Utah}$, which adopted the reserve plan in 1935, substituted for it in August, r936, the pooled fund with merit ratings. 
keeping for each state in the administration of its unemployment compensation and for the United States in connection with the collection of the tax and the payment of old age benefits. Our Federal-State Employment Service must be expanded and improved. In Great Britain, the last count made showed only about twenty-five per cent of the jobs obtained by the unemployed workers covered by the British Act are secured by the National Employment Exchange. ${ }^{59}$ As the British system was organized on a national basis more than twenty-five years ago, there is no basis for thinking that our Federal-State Employment Service can for some years to come equal the record of the British. And yet we must rely on the employment service to determine whether or not an unemployed man can get a job before he is eligible for benefits. Just as in the interpretation of workmen's compensation legislation, there will be many issues to decide in connection with determining eligibility for benefits. For example, questions are certain to arise as to whether a worker was dismissed for cause, or whether there was a strike or lockout, whether he was able to work, etc. In connection with these and many other questions, the investigators for the state agency administering unemployment compensation and the appeal boards will gradually build up a definition of what constitutes unemployment under our laws.

The National Security Board is not given general supervisory power over the state systems, but it can pass on the effectiveness of state administration in connection with approval of the state law and grants for administrative costs. With this power a national agency should be able to help in building up effective state administration. A board is, however, not administratively effective nor can it handle state relationships as successfully as a unified administrative agency. Confusion, delay, and misunderstanding are all too likely to result from the board type of administration which Congress has set up. If, instead of a full-time administrative board, the Security Board could be made an unpaid or parttime board with authority only to pass on broad policies and decide appeals from the states, it would be more useful. The newly created British Unemployment Council of Social Insurance, a board of experts reporting its recommendations directly to the House of Commons, has not as yet had time to demonstrate its value.

\section{AFTER EARNED BENEFITS ARE EXHAUSTED, WHAT?}

Reference has been made to the fact that the weakness of the English system at the beginning of the post-war period was that no plan had been

${ }^{59}$ Royal Commission on Unemployment Insurance, Minutes of Evidence 453 (Feb. I9, 1931). 
adopted for those who were unemployed and had exhausted their earned benefits and that a double decker plan had been adopted by the National Government in I934. No such second tier plan has as yet been adopted by the federal government or by any state. In general, after a waiting period of three weeks, benefits provided under the state laws adopted to date become payable for a period of sixteen weeks at the rate of fifty per cent of the wages, with a maximum of $\$$ I 5 a week and a minimum of $\$ 5$ or $\$ 7$ or no minimum. Whether the tax levied may make possible a shorter waiting period or a longer period of benefits or both, experience alone will show. But at any rate it is clear that the need of many workers will not be met by this system and that poor relief does not provide an adequate supplementary form of assistance. The President's Committee on Economic Security evidently canvassed this subject and reported as follows with reference to the type of assistance that should be provided when the benefit period is ended:

We regard work as preferable to other forms of relief where possible. While we favor unemployment compensation in cash, we believe that it should be provided for limited periods on a contractual basis and without governmental subsidies. Public funds should be devoted to providing work rather than to introducing a relief element into what should be strictly an insurance system..$^{60}$

No commitment was made by the committee on the question of a means test for such work. In general, the plan they approve is similar to WPA, so that something is known of the possibility and the cost of supplying work to some fifty per cent of the unemployed in need of help after their statutory benefits are exhausted. In spite of the great superiority of work over other forms of assistance, there are many practical difficulties in making it the only form of assistance. Certainly, WPA has demonstrated that even with large expenditure of funds and great ingenuity in the discovery of work suited to different types of skills, useful employment cannot be provided all employables in non-competitive work. Not only has it been impossible in these extraordinary times, but in normal times it can hardly be expected that a work project can be set up whenever one or more persons in any part of the country have exhausted their work benefits under the unemployment compensation law. If federal aid is restricted to providing work, the experience of the past year indicates that the families of many unemployed workers will be inadequately supported on poor relief.

WHAT THE SECURITY ACT DOES NOT DO

There are two methods of evaluating the Social Security Act-one can ask how much it does or what it does not do. If we ask the latter question,

${ }^{60}$ Report of the Committee on Economic Security 4 (I935). 
we find that as farm labor, domestic servants, teachers, social workers, etc., are not included, the old age annuity program will cover only a little more than half of all gainfully employed persons. In addition to the employed persons not included, most wives of the workers will not be covered, and small tradespeople and others working on an independent basis will not receive old age annuities. Whether they can secure old age assistance after a demonstration of need will depend upon the state old age assistance laws. As for unemployment compensation, if the states include, as the federal tax does, only those who are employers of eight or more persons, approximately forty-six per cent of the employed persons will be insured. A measure of security is thus provided for some 23,000,000 workers, but not all those who need such protection. The Security Act therefore accomplishes much but not all that is needed to protect aged and unemployed workers. Moreover, the act makes no provision for sickness insurance, one of the hazards which is usually much feared by the workers after they reach middle age.

THE HAZARD OF SICKNESS

Ill health is one of the most common causes of dependency. When it attacks the wage-earner, his wages cease and his future earning capacity often depends upon the kind of medical care he receives. But in addition to the incapacity that may come to him, the serious illness of his wife or children often means the accumulation of debts, the loss of credit with landlord and store-keeper, and finally an appeal for relief. The German and English method of compulsory contributory sickness insurance for employed workers was widely discussed in the United States between I9I 2 and 1920 , but with the doctors and employers opposed, and organized labor showing no great enthusiasm for the compulsory contributory system, no laws were passed. Public discussion of the subject was not renewed until in I932, when the report of the Committee on the Cost of Medical Care showed a majority in favor of a voluntary insurance system. ${ }^{6 x}$ During the depression, large numbers of doctors for the first time learned what insecurity means to them and began to study with a new interest the panel system of the British Health Insurance Act, which at least assured rent and other fixed charges to the insurance doctors. They were therefore more ready to listen to proposals than twenty years ago. But the report of the Committee on the Cost of Medical Care satisfied neither the doctors nor the advocates of a real medical care program.

\footnotetext{
6x Medical Care for the American People: Final Report of the Committee on the Cost of Medical Care, Publication No. 28, pp. r20-2I (r932).
} 
The discussion of the objections to so-called "state medicine" in relation to the existing unmet need for medical care began anew. A medical advisory committee to the Cabinet Committee on Economic Security considered proposals for a sickness insurance scheme, but an agreement was not reached in I934 and it was therefore directed to continue its work. The Report to the President of the Committee on Economic Security ${ }^{62}$ recognized that "illness is one of the major causes of economic insecurity which threaten people of small means in good times as in bad"; that "in normal times from one-third to one-half of all dependency can be traced to the economic effects of illness." "63 While making no specific recommendation, the committee stated "the board principles" which it considered "fundamental" for a "sound plan of health insurance." Its only specific recommendation was that "cash payments in partial replacement of wage loss due to sickness" should be administered in connection with unemployment compensation, and that the provision of medical services should be a federal-state undertaking. ${ }^{6}$ The costs of a cash payment for wage loss during sickness on substantially the same basis as unemployment compensation, i.e., fifty per cent of wages for a maximum period of fifteen weeks, the committee reported would require a one to one and one-fourth per cent payroll tax.65 The costs of medical care it found to be "not primarily a problem of finding new funds, but of budgeting present expenditures so that each family or worker carries an average risk rather than an uncertain risk." "66 The committee thus committed itself to the compulsory contributory system for medical services as well as for cash benefits. It did not discuss in its report the advantages or objections to meeting the costs of medical care out of general taxes, instead of by a special levy. An important beginning has been made in public provision of medical care for certain specific diseases, for example, for mental disease, tuberculosis, cancer in a few states, orthopedic treatment for crippled children in most states, and for general care in the state hospitals which have been established in connection with the medical schools of the state universities of Colorado, Iowa, Michigan, Minnesota, and Wisconsin, as well as in public municipal and county charity hospitals. It is not possible here to enumerate the inadequacies of the British health insurance system, which provides medical examination and treatment of minor diseases for employed persons only. This leaves the problem of hospital care, medical care for married women not employed outside their own homes, for children, and those of small income who are not in an employed status, still unsolved.

62 U.S. Government Printing Office, Washington, I935.
${ }^{6}$ Id. at 38 .
${ }^{6} \mathrm{Id}$. at 42 .
65 Id. at 43 .
${ }^{66}$ Ibid. 
While it was expected in 1934, when the Committee on Economic Security reported to the President that agreement on a plan would be reached early in 1935 by its Medical Advisory Committee, no report has as yet been made public. The American Medical Association has continued its opposition, and the Milbank Memorial Fund, which for several years had John Kingsbury, Edgar Sydenstricker, and I. S. Falk at work on the actuarial, medical, and other problems of health insurance, is reported to have given up its work in this field and dismissed ${ }^{67}$ its secretary, Mr. Kingsbury, as a result of medical pressure. Grants-in-aid for the prevention of sickness and medical care for crippled children have been provided by the Security Act but we shall still have no care, or inadequate medical care for many wage earners and their families, with the resulting dependency and lowered efficiency of the worker, unless some nationalstate program for medical care is adopted.

RELIEF STILL A FIRST IINE OF DEFENSE

The Security Act clearly does not mean an end of relief. In a short time, it is true, all but a very small number of the aged should be "off relief"; the provision of the grants-in-aid for dependent children is inadequate, and supplementation will be necessary in many states; no provision is yet made in any state for assistance to the unemployed after the out-ofwork benefits are exhausted; the sick must still depend upon relief, as well as all those who are temporarily or permanently unemployable for other reasons. Moreover, benefits which are fixed by law on a percentage of earnings and not a need basis will often be inadequate. For example, fifty per cent of the earnings of an unskilled worker with a large family will not be enough to feed the children, and supplemental relief for him and his family will often be necessary, even while he is being paid unemployment benefits.

While the Security Act takes us a long way toward security, then, it leaves much undone. Certainly, relief will still be needed. It is therefore important to substitute modern assistance laws for the old pauper relief. Moreover, if the whole system is to be on an adequate basis, this residual relief program should be supported by federal, state, and local governments.

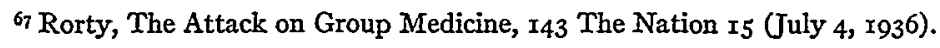

